\title{
Feeding frequency on the production viability of production and quantitative descriptors of parasitism in angelfish
}

\author{
Frequência alimentar na viabilidade de produção e na \\ descrição quantitativa de parasitas em acará bandeira
}

\author{
Rodrigo Yudi Fujimoto ${ }^{I}$ Rudã Fernandes Brandão Santos ${ }^{\text {II }}$ Henrique Malta Dias ${ }^{\text {II }}$ \\ Fabrício Menezes Ramos ${ }^{\mathrm{III}}$ Derlan José Ferreira Silva ${ }^{\mathrm{III}}$ Claucia Aparecida Honorato ${ }^{\mathrm{IV}}$
}

\section{ABSTRACT}

Angelfish (Pterophyllum scalare) is a very important species in Brazil's domestic market, however feeding managements differ from fish breeders to aquarists, so the cost of feed and labor become relevant items when cultivating the species. The objective of this research was to assess feeding frequency and feed deprivation based on growth performance, parasite infestation and costbenefit in farming this species. The experiment was conducted in a completely randomized design in a $3 \times 2$ factorial scheme with 3 daily feeding levels, 4 meals, 2 meals and 1 meal; with and without feed deprivation and two repetitions. Feed deprivation consisted of offering feed 5 days a week only. Feeding twice a day without deprivation and four times a day with or without feed deprivation resulted in higher growth performance than feeding once a day. Monogenean and nematode parasitic loads were not influenced by feeding management. The cost-benefit analysis enabled us to observe that the treatment with the best benefit was the one involving two feedings a day with no deprivation. Thus, considering the parameters mentioned above, we concluded that the two daily feedings with no feed deprivation is the most adequate for farming this specie.

Key words: Pterophyllum Scalare, feed management, ornamental fish. RESUMO

O acará bandeira (Pterophyllum scalare) é uma espécie muito importante no mercado interno do Brasil, no entanto o manejo alimentar difere entre os criadores de peixes para os aquaristas, levando em consideração o custo da alimentação e mão de obra. $O$ objetivo deste trabalho foi avaliar o efeito da frequência de alimentação no desempenho na infestação do parasita e custo-beneficio em acará bandeira de cultivo. O ensaio foi conduzido em um delineamento inteiramente casualizado em um esquema fatorial 3x2, sendo niveis de alimentação diários (4, 2 e 1 refeições) e 2 manejos (com e sem privação de alimentação), cada tratamento com duas repetições. Alimentação duas vezes por dia sem privação e quatro vezes por dia, com ou sem alimentação resultou no desempenho de crescimento, cargas parasitárias de monogeneas e nematoides não foram influenciados pelo manejo alimentar. A análise de custo-beneficio nos permitiu observar que o tratamento envolvendo duas refeições por dia com nenhuma privação foi melhor. Conclui-se que o tratamento com duas refeições diárias sem privação alimentar é a mais adequada para o cultivo dessa espécie.

Palavras-chave: Pterophyllum scalare, manejo alimentar, peixes ornamentais.

\section{INTRODUCTION}

The ornamental fish trade is considered one of the most lucrative sectors in fish farming in Brazil (RIBEIRO et al., 2009). Angelfish Pterophyllum scalare (Lichtenstein) is a cichlid in great demand due to its beauty, reproductive capacity and adaptability to captivity; in consequence, the economic potential of the species is also high (CHAPMAN et al., 1997).

In intensive systems, ornamental fish farming is characterized by the use of aquaria and water recirculation systems (RIBEIRO et al., 2009). In such systems, extruded feed provides better growth performance (RODRIGUES \& FERNANDES, 2006),

\footnotetext{
'Embrapa Tabuleiros Costeiros, Aracaju, SE, Brasil.

"Laboratório de Patologia de Organismos Aquáticos (LAPOA), Centro de Aquicultura da Unesp (CAUNESP). Universidade Estadual Paulista "Júlio de Mesquita Filho" (UNESP), Jaboticabal, SP, Brasil.

"IIUniversidade Federal do Pará (UFPA), Bragança, PA, Brasil.

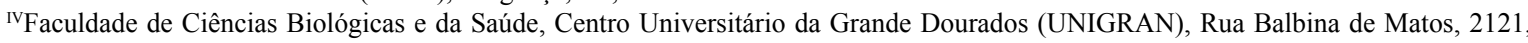
Jardim Universitário, 79824-900, Dourados, MS, Brasil. E-mail: clauciahonorato@yahoo.com.br. Corresponding author. 
the ideal level of protein falling between 32 and $47 \%$ crude protein (ZUANON et al., 2006) and the level of gross energy between 3100 and $3300 \mathrm{kcal}$ of digestible energy kg-1 of feed (ZUANON et al., 2009).

Determining the feeding management is important because it allows the producer to know the quantity of food to be offered to animals in culture, improving the productive results (ARIES \& MIKOS, 2005; RIBEIRO, 2008). Furthermore, feed deprivation management also stimulates compensatory growth, physiological process in which the organism accelerates growth following the period of restricted development to reach the weight of animals that did not suffer deprivation (HORNICK et al., 2000).

In recent years, the culture of ornamental fish in Brazil has shown rapid development, but there is still little information about the parasites that may compromise their production (PIAZZA et al., 2006). TAVARES-DIAS et al. (2009) reports the Monogenea among the most common helminthes parasites in ornamental farmed fish, (PIAZZA et al., 2006) related to the pathogenicity of these parasites and to mechanical damage produced in the gills and skin of the host (GARCIA et al., 2003; PIAZZA et al., 2006). In discus-flags, the nematodes found most often are the genus Capillaria sp., that when in large numbers, can cause apathy, intestinal obstruction, chronic fasting and death (FUJIMOTO et al., 2006).

The objective of this study was to assess feeding frequency and deprivation based on growth performance, parasite infestation and cost-benefit in angelfish farming.

\section{MATERIAL AND METHODS}

The aquaria were provided with artificial aeration as well as biological and mechanical filtration. The experimental units were kept in an environment with natural temperature and lighting (12h light, $12 \mathrm{~h}$ dark). To measure the $\mathrm{pH}$ and the temperature was used YSI 60, dissolved oxygen was measured with YSI 550A. These parameters were monitored daily. The ammonia was monitored once a week with Hanna HI 93715 equipment. Water was changed twice a week by siphoning in order to remove feces from aquaria floors.

The experiment was performed in a completely randomized design in a $3 \times 2$ factorial scheme consisting of 3 daily feeding levels, 4 meals, 2 meals and 1 meal, and two feed deprivation managements and two repetitions (Table 1). Feeding

Table 1 - Growth performance rates for angelfish submitted to feed with one, two or four daily feeds with or without food restriction two days a week.

\begin{tabular}{|c|c|c|c|c|}
\hline Parameters & Feed Deprivation & 4 meals day ${ }^{-1}$ & 2 Meals day ${ }^{-1}$ & 1 meal day ${ }^{-1}$ \\
\hline \multirow{2}{*}{ Biomass (g) } & without & $36.2 \pm 2.7 \mathrm{Aa}$ & $36.8 \pm 1.8 \mathrm{Aa}$ & $26 \pm 0.3 \mathrm{Ab}$ \\
\hline & with & $39.5 \pm 0.8 \mathrm{Aa}$ & $30.8 \pm 2.0 \mathrm{Bb}$ & $22.8 \pm 0.4 \mathrm{Ac}$ \\
\hline \multirow{2}{*}{ Density $\left(\mathrm{g} \mathrm{L}^{-1}\right)$} & without & $0.8 \pm 0.06 \mathrm{Aa}$ & $0.8 \pm 0.04 \mathrm{Aa}$ & $0.5 \pm 0.007 \mathrm{Ab}$ \\
\hline & with & $0.8 \pm 0.01 \mathrm{Aa}$ & $0.6 \pm 0.04 \mathrm{Bb}$ & $0.5 \pm 0.01 \mathrm{Ac}$ \\
\hline \multirow{2}{*}{ Final weight (g) } & without & $4.0 \pm 0.3 \mathrm{Aa}$ & $4.0 \pm 0.2 \mathrm{Aa}$ & $2.8 \pm 0.03 \mathrm{Ab}$ \\
\hline & with & $4.1 \pm 0.09 \mathrm{Aa}$ & $3.4 \pm 0.2 \mathrm{Bb}$ & $2.5 \pm 0.05 \mathrm{Bc}$ \\
\hline \multirow{2}{*}{ Weight gain $(\mathrm{g})$} & without & $1.9 \pm 0.3 \mathrm{Aa}$ & $1.6 \pm 0.1 \mathrm{Aa}$ & $0.5 \pm 0.09 \mathrm{Ab}$ \\
\hline & with & $1.5 \pm 0.9 \mathrm{Aa}$ & $0.9 \pm 0.5 \mathrm{Bb}$ & $0.09 \pm 0.05 \mathrm{Ac}$ \\
\hline \multirow{2}{*}{ SGR $\left(\%\right.$ day $\left.^{-1}\right)$} & without & $0.8 \pm 0.10 \mathrm{Aa}$ & $0.8 \pm 0.06 \mathrm{Aa}$ & $0.3 \pm 0.07 \mathrm{Ab}$ \\
\hline & with & $0.9 \pm 0.01 \mathrm{Aa}$ & $0.5 \pm 0.06 \mathrm{Bb}$ & $0.06 \pm 0.03 \mathrm{Bc}$ \\
\hline \multirow{2}{*}{ FER } & without & $2.3 \pm 0.04 \mathrm{Aa}$ & $1.7 \pm 0.4 \mathrm{Aa}$ & $2.4 \pm 0.01 \mathrm{Aa}$ \\
\hline & with & $2.1 \pm 0.20 \mathrm{Aa}$ & $1.4 \pm 0.22 \mathrm{Aa}$ & $10.2 \pm 0.10 \mathrm{Bb}$ \\
\hline \multirow{2}{*}{$\mathrm{KN}$} & without & $1.00 \pm 0.07 \mathrm{Aa}$ & $0.94 \pm 0.11 \mathrm{Aa}$ & $1.06 \pm 0.11 \mathrm{Aa}$ \\
\hline & with & $1.00 \pm 0.08 \mathrm{Aa}$ & $1.00 \pm 0.09 \mathrm{Aa}$ & $0.92 \pm 0.15 \mathrm{Ba}$ \\
\hline
\end{tabular}

Means in columns followed by same capital letters and means in lines followed by lowercase letters not presents differences by Tukey test $(\mathrm{P}>0.05)$. SGR: specific growth ratio; FER: feed efficiency ratio; KN: relative condition factor.

Ciência Rural, v.46, n.2, fev, 2016. 
times determined for each treatment were, for one feeding, at 8am; 2feedings, $8 \mathrm{am}$ and 6pm; and for 4 feedings, at $8 \mathrm{am}, 11 \mathrm{am}, 3 \mathrm{pm}$ and $6 \mathrm{pm}$. The feed used in this research was provided by the Poytara animal feeding factory and possessed the following chemical composition: humidity $(\max ) 10 \%$; fibrous matter $(\max ) 4 \%$; mineral matter $(\max ) 9 \%$; calcium $(\max )$ $2 \%$; phosphorus (min) $1 \%$; crude protein (min) $35 \%$; and ethereal extract (min) $3.5 \%$.

Experimental design of this experiment: 1 daily feeding without food restriction, 2 daily feeding without food restriction, 4 daily feeding without food restriction, 1 daily feeding with food restriction (two days), 2 daily feeding with food restriction (two days), 4 daily feeding with food restriction (two days).

In order to assess the performance of the animals at the end of the experimental period it was performed biometrics measuring with the following variables: weight $(\mathrm{g})$; standard length $(\mathrm{cm})$; biomass (g); final stocking density $\left(\mathrm{g} \mathrm{L}^{-1}\right)$; weight gain (WG, in $\mathrm{g}$ ); feed consumption ( $\mathrm{g}$ ); individual feed consumption per meal, calculated by dividing the fish's feed intake in each replicate by the quantity of meals; feed efficiency ratio (FER); and specific growth rate (SGR, in \%). It was also calculated the survival rate $(\%)$ and the relative condition factor (Kn) (LIMA-JÚNIOR et al., 2002).

Was realized a production cost analysis estimated in the best two treatments. Due to the similarity in costs such as electricity, infrastructure and consumable goods (sieves, buckets, nets, etc.) they were not part of the assessment. Only filter and aquaria costs were considered. Two feed prices were considered (U\$\$ 25 and U\$\$ $50 \mathrm{~kg}^{-1}$, average market prices for this type of feed). Labor was calculated taking into consideration feeding times of 30 s per meal. The minimum wage considered was US $\$ 243.24$ plus $40 \%$ for labor rights and overtime. The selling price considered for angelfish specimens was US\$1.03 for small fish and US\$2.02 for mediumsized fish. The commercial classification considered was the one adopted in Brazil, according to which small fishes measure between 3.5 and $4.5 \mathrm{~cm}$, mediumsized fishes measure between 4.5 and $6.5 \mathrm{~cm}$ and large fishes measure 6.5 to $8 \mathrm{~cm}$ (RIBEIRO, 2008). With this data we calculated the cost-benefit ratio (CBR) using the equation $\mathrm{CBR}=\mathrm{Costs} /$ revenues generated.

The end of the experiment $33 \%$ of the fish from each treatment were sacrificed by cerebral concussion. In order to collect the monogeans the gills were removed, the arches were separated, fixed, and were counted. For nematodes, we analyzed the digestive tract and performed the count (EIRAS et al.
2006) and identification according to thatcher (2006). Parasitological indices were calculated according to Bush et al. (1997).

All data were submitted to the ShapiroWilk normality test. Once normal distribution was ascertained, the data was submitted to analysis of variance (one-way or two-way ANOVA, $\mathrm{P}=0.01$ ) and since $\mathrm{F}$ was significant, we performed Tukey's test $(\mathrm{P}<0.05)$ to compare the means.

\section{RESULTS AND DISCUSSION}

Dissolved oxygen, temperature, $\mathrm{pH}$ and ammonia values did now show significant difference ( $\mathrm{P}>0.05$ ), remaining within the values recommended for this fish species (URBINATI \& GONÇALVES, 2005). There was no mortality during the trial period. Productive performance was positively affected by food frequency. The food deprivation had no significant effect in treatments with four daily feeds (Table 2).

Management of four-meals-a-day caused increase in total feed consumption. However, the opposite was observed regarding the individual feed consumption per meal parameter (Figure 1B), indicating hyperphagia in treatments where food frequency was lowest.

SANTOS et al. (2010) did not observe any changes in the consumption of fish feed Colossoma macrompomum or not subjected to food deprivation diets evaluated with different protein levels. FOURNIER et al. (2003) characterized as hyperphagia the nutritional mechanism used by fish to compensate the nutritional deficiency of a particular diet. DE LA HIGUERA (2001) observed this behavior in trout receiving in their diets insufficient doses of zinc. In the present study the treatments with less dietary caused this increase in feed consumption to mitigate the effects of reduced intake of food.

In the one-meal-a-day treatment, food deprivation negatively influenced the final weight, weight gain, SGR and FER, as well as condition factor rates DWYER et al. (2002) evaluated one, two and four meals per day and two meals every other day and found that there was a decrease in weight gain with decreased food frequency. CARNEIRO \& MIKOS (2005) evaluated the food frequency in a South American catfish, R. quelen, which was fed only once a day and did not show any worsening of the growth performance due to higher feed storage capacity in the stomach for a prolonged period.

The value of the condition factor $(\mathrm{Kr}=6.1 \pm 12: 11)$ obtained in the present study is within the recommended for this species (TAVARES-DIAS et al., 2008). The same result is the weight/length 
Table 2 - Prevalence and mean intensity of Sciadicleithrum phithimum in gills and Capillaria sp. of in angelfish fed with one, two or four daily feeds with or without food restriction two days a week.

\begin{tabular}{|c|c|c|c|c|c|}
\hline & Gills & Stomach & Anterior intestine & Medium intestine & Posterior intestine \\
\hline 4 meals day $^{-1}$ & $91.6 \pm 16.6$ & $66.6 \pm 57$ & $91.7 \pm 16.6$ & $83.3 \pm 10.6$ & $41.6 \pm 16.6$ \\
\hline 2 meals day ${ }^{-1}$ & $100 \pm 0$ & $8.3 \pm 16.6$ & $66.6 \pm 27.2$ & $66.6 \pm 4.5$ & $50 \pm 43$ \\
\hline 1 meal day $^{-1}$ & $75 \pm 31.9$ & $39.5 \pm 18.4$ & $58.3 \pm 70$ & $38.7 \pm 7.6$ & $25 \pm 31.9$ \\
\hline With out food deprivation & $94.4 \pm 13.6$ & $37.5 \pm 39.3$ & $83.3 \pm 18$ & $64.7 \pm 3.9$ & $44.4 \pm 40$ \\
\hline \multirow[t]{2}{*}{ Food deprivation } & $83.3 \pm 27.8$ & $38.8 \pm 40.8$ & $61.1 \pm 43$ & $61.1 \pm 9.6$ & $33.3 \pm 21$ \\
\hline & Gills & Stomach & Anterior intestine & Medium intestine & Posterior intestine \\
\hline 4 meals day ${ }^{-1}$ & $11.9 \pm 1.4 \mathrm{~A}$ & $2.2 \pm 1.9 \mathrm{~A}$ & $8.3 \pm 10.6 \mathrm{~A}$ & $5 \pm 2.54 \mathrm{~A}$ & $2.1 \pm 4 \mathrm{~A}$ \\
\hline 2 meals day $^{-1}$ & $5.4 \pm 3.2 \mathrm{~A}$ & $0.75 \pm 1.5 \mathrm{~A}$ & $8.2 \pm 4.5 \mathrm{~A}$ & $15.3 \pm 11.6 \mathrm{~A}$ & $1.8 \pm 1.6 \mathrm{~A}$ \\
\hline 1 meal day $^{-1}$ & $14.75 \pm 13 \mathrm{~A}$ & $9.3 \pm 10.6 \mathrm{~A}$ & $9.8 \pm 7.63 \mathrm{~A}$ & $7.6 \pm 10.5 \mathrm{~A}$ & $4.1 \pm 3.6 \mathrm{~A}$ \\
\hline With out food deprivation & $11.5 \pm 13 \mathrm{a}$ & $2.6 \pm 2.6 \mathrm{a}$ & $7.1 \pm 3.9 \mathrm{a}$ & $9.08 \pm 8.8 \mathrm{a}$ & $2.5 \pm 2.8 \mathrm{a}$ \\
\hline Food deprivation & $9.9 \pm 9.6 \mathrm{a}$ & $5.5 \pm 9.6 \mathrm{a}$ & $10.4 \pm 9.6 \mathrm{a}$ & $9.5 \pm 10.9 \mathrm{a}$ & $2.9 \pm 3.6 \mathrm{a}$ \\
\hline
\end{tabular}

is used to determine the overall condition of fish, both in the wild and in captivity (BRAGA, 1997), sound (TAVARES-DIAS et al., 2000) or infected (TAVARES-DIAS et al., 1999). Fish in good health condition with adequate weight / length is generally of isometric type (CHAVES, 1998).
In two-meals-a-day treatment with feed deprivation, there was a reduction in growth performance. SOARES et al. (2007), submitted Cichla sp. to feed deprivation for 2 and 1 days a week for 30 days. They identified that the control treatment, which was not subjected to food deprivation showed the best results.

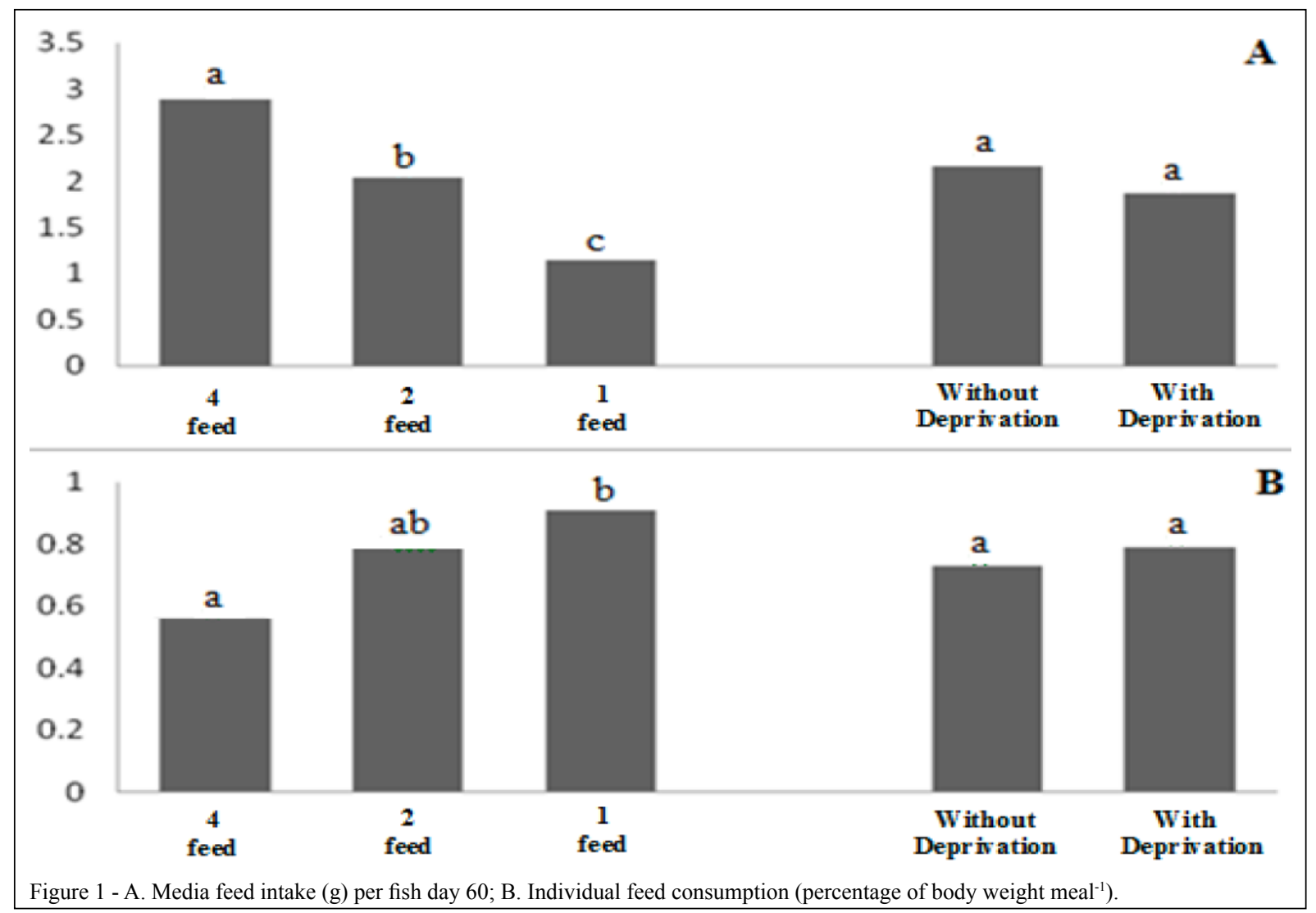

Ciência Rural, v.46, n.2, fev, 2016. 
The growth performance values of fish in 4-meals-a-day treatment with or without feed deprivation is the same as for fish which receive two meals a day with weekly deprivation (Table 2). KASIRI (2011) didn't observe significant difference either in the performance of angelfish with initial weight of $0.87 \mathrm{~g}$ receiving four or two meals a day. These results demonstrate similar results for the two weight ranges used in both studies. These results also show that the treatments that received two daily meals had the same performance as those who received four meals a day indicating that power excess can diminish food efficiency.

The 4-meals-a-day treatment with feed deprivation compared to four meals a day with no deprivation showed no difference in feed efficiency ratio value. These results indicate that there was a compensatory weight gain in fish subjected to this treatment than those who were not exposed to starvation. This is in agreement with BARAKAT et al. (2011), who affirmed that shorter food deprivation periods are more adequate than longer periods due to the intense metabolism and quick growth rate of tropical fish.

Regarding the fish's parasite fauna, the differences were observed in the prevalence and mean intensity in the gills, stomach and intestine (anterior, posterior and fear), table 3. Of the 941 parasites collected, Sciadicleithrum phithimum monogeneans found were parasitizing the gills and the Capillaria sp. nematodes were parasitizing the digestive tract. For monogeans, similar prevalence and mean intensity values were reported in wild and naturally infected angelfish, with $92 \%$ of prevalence and mean intensity of $12.2 \pm 4.2$ (TAVARES-DIAS, 2009).

Table 3 - Cost-benefit for treatments with 2 meals a day without feed deprivation and 4 meals a day with feed deprivation.

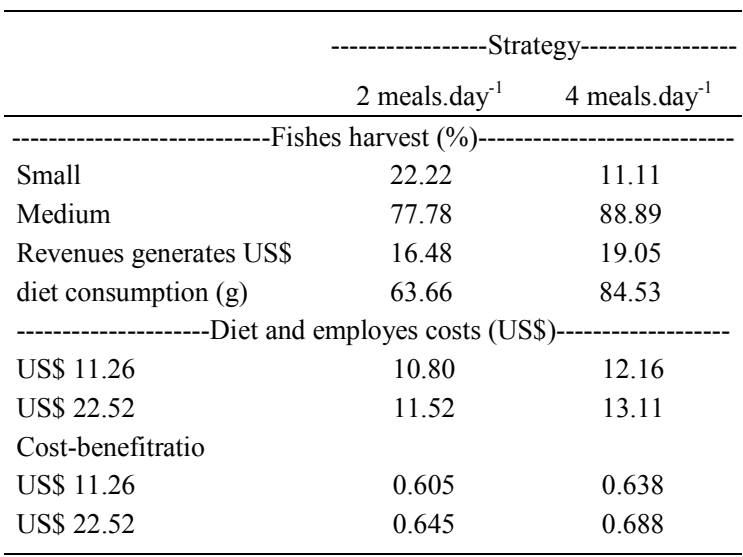

The results suggested that there was no effect of the managements adopted. Although the parasite prevalence was high, near $90 \%$, nematodes have a direct life cycle, which did not favor an increase in parasitic infestation by nematodes. These results demonstrate that the host-parasite relationship was not compromised by the food frequency and food deprivation adopted in the different treatments. The condition factor reinters this statement. TAVARESDIAS et al. (2002) noted that in O. niloticus, $\boldsymbol{L}$. macrocephalus and $\boldsymbol{P}$. mesopotamicus parasitized decrease in conditions regarding these not infested fish.

The treatment with 4 meals a day with food deprivation, was the only feeding regime application of this concept based on compensatory weight gain (METCALFE \& MONAGHAN, 2001) under productive aspect. The 4-meal feed management with deprivation and the 2-meal feed management without deprivation have similar sanitary aspects and growth performance. They are different in the amount of labor used which in practice influences production costs.

It can be observed that the revenue from the 4-meals-a-day treatment was higher in comparison to the 2-meals-a-day management without deprivation. However, considering the values of the food and overtime in Brazil, the costs involving two meals a day with no weekly feed deprivation were lower. Therefore, considering cost-benefit, the treatment of 2 meals a day without feed deprivation is the most recommended management.

\section{CONCLUSION}

The one-meal-a-day management with no deprivation can be used when the objective is maintaining fish weight. The two-daily feeding management without deprivation is the best management providing better growth performance associated with a better cost-benefit ratio without harming fishes health.

\section{BIOETHICS AND BIOSSECURITY COMMITTEE APPROVAL}

CEUA process 004/14.

\section{ACKNOWLEDGEMENT}

Conselho Nacional de Desenvolvimento Científico e Tecnológico (CNPQ) to the granting scientific initiation scholarship to the authors. The Fundação Amazônia Paraense de Amparo a Pesquisa (FAPESPA) for project financing. The Poytara for the feed supply used in the experiment. 


\section{REFERENCES}

BARAKAT A. et al. Feed regimen affects growth, condition index, proximate analysis and myocyte ultrastructure of juvenile spinefoot rabbitfish Siganus rivulatus. Aquaculture Nutrition. v.17, n.3, p.773-780, 2011. Available from: <http://onlinelibrary.wiley.com/ doi/10.1111/j.1365-2095.2010.00847.x/abstract>. Accessed: Nov. 2014. doi: 10.1111/j.1365-2095.2010.00847.x.

BRUSH, A.O.K. et al. Parasitology meets ecology on its own terms: Morgolis et al. revisited. Journal of Parasitology. v.83, p.575-583, 1997. Available from: <http://www.jstor.org/ iscover $/ 10.2307 / 3284227$ ?uid $=2 \&$ uid $=4 \&$ sid $=21105244608053>$. Accessed: Nov. 2014

CARNEIRO, P.C.F.; MIKOS, J.D. Freqüência alimentar e crescimento de alevinos de jundiá, Rhamdia quelen. Ciência Rural, v.35, n.1, p.187-191, 2005. Available from: <http://www.scielo.br/ scielo.php?pid $=$ S0103-84782005000100030\&script $=$ sci arttext $>$. Accessed: Nov. 2014. doi: 10.1590/S0103-84782005000100030.

CHAPMAN, F.A. et al. United States of America trade in ornamental fish. Journal World Aquature Socity, v.28, p.1-10, 1997.

DE LA HIGUERA, M. Effects of nutritional factors and feed characteristics on feed intake. In: HOULIHAN, D. et al. (Eds.). Food intake in fish. Ames: Iowa State Univ, 2001. p.250-268.

DWYER, K.S. Feeding frequency affects food consumption, feeding pattern and growth of juvenile yellowtail flounder (Limanda ferruginea). Aquaculture, v.213 p.279-292, 2002.

EIRAS, J.C. et al. Métodos de estudo e técnicas laboratoriais em parasitologia de peixes. 2.ed. Maringá: Eduem, 2006. p.199.

FOURNIER, V. et al. Excess dietary arginine affects urea excretion but does not improve $\mathrm{N}$ utilisation in rainbow trout Oncorhynchus mykiss and turbot Psetta maxima. Aquaculture, v.217, p.559-576, 2003.

GARCIA, F. et al. Parasitismo de Xiphophorus spp. por Urocleidoides sp. e sua relação com os parâmetros hídricos. Boletim do Instituto de Pesca, v.29 p.123-131, 2003.

HORNICK, J.L. et al. Mechanisms of reduced and compensatory growth. Domestic Animal Endocrinology, v.19, p.121132, 2000. Available from: <http://www.ncbi.nlm.nih.gov/ pubmed/11025191>. Accessed: Nov. 2014.

KASIRI, M. et al. Effects of feeding frequency on growth performance and survival rate of angel fish, Pterophyllum scalare (Perciformes, Cichlidae). Veterinary Research Forum, v.2, n.2, p.97-102, 2011. Available from: <http://www.urmia.ac.ir/vrf/Shared\%20Documents/ pdf/vol-2\%20no-2/97-.pdf>. Accessed: Nov. 2014.

LIMA-JUNIOR, S.E.; GOITEIN, R. Fator de condição e ciclo gonadal de fêmeas de Pimelodus maculatus (Osteichthyes, Pimelodidae) no rio Piracicaba (SP, Brasil). Boletim do Instituto de Pesca, v.32, n.1, p.87-94, 2006. Available from: <ftp://ftp. sp.gov.br/ftppesca/32_1_87-94.pdf>. Accessed: Nov. 2014.

METCALFE, N.B.; MONAGHAN, P. Compensation for bad start, grow now, pay later? Trends in Ecology \& Evolution, v.16, p.254-260, 2001. Available from: <http://www.sciencedirect.com/ science/article/pii/S0169534701021243>. Accessed: Nov. 2014. doi: 10.1016/S0169-5347(01)02124-3.

RIBEIRO, F.A.S. Sistemas de criação para o acará-bandeira Pterophyllum scalare. Acta Scientiarum, v.30, n.4, p.459-466, 2008. Available from: <http://periodicos.uem.br/ojs/index.php/ ActaSciAnimSci/article/view/685>. Accessed: Nov. 2014. doi: 10.4025/actascianimsci.v30i4.685.
PIAZZA, R. et al. Parasitic diseases of freshwater ornamental fishes commercialized in Florianópolis, Santa Catarina, Brazil. Boletim do Instituto de Pesca, v.32, n.1, p.51-57, 2006.

RIBEIRO, F.A.S. et al. Cadeia produtiva do peixe ornamental. Panorama da Aquicultura, v.19, n.112, p.34-45, 2009.

RODRIGUES, L.A.; FERNANDES, J.B.K. Influencia do processamento da dieta no desempenho produtivo do acarabandeira (Pterophyllum scalare). Acta Scientiarum, v.28, n.1, p.113-119, 2006. Available from: <http://periodicos.uem.br/ojs/ index.php/ActaSciAnimSci/article/view/847>. Accessed: Nov. 2014. doi: $10.4025 /$ actascianimsci.v28i1.847.

SANTOS, L. et al. Exigência protéica de juvenis de tambaqui (Colossoma macropomum) após privação alimentar. Acta Amazônica, v.40, n.3, p.597-604, 2010. Available from: $<$ https://acta.inpa.gov.br/ fasciculos/40-3/PDF/v40n3a21.pdf $>$. Accessed: Nov. 2014.

SOARES, E.C. et al. Condicionamento alimentar no desempenho zootécnico do tucunaré. Revista Brasileira de Engenharia de Pesca, v.2, p.35-48, 2007. Available from: <http://ppg.revistas.uema.br/ index.php/REPESCA/article/viewFile/50/54>. Accessed: Nov. 2014.

TAVARES-DIAS, M. et al. Parasitic fauna of eight species of ornamental freshwater fish species from the middle Negro River in the Brazilian Amazon Region. Revista Brasileira de Parasitologia Veterinária, v.19, p.29-33, 2009. Available from: <http://www. scielo.br/scielo.php?pid=S1984-29612010000200007\&script $=$ sci arttext>. Accessed: Nov. 2014. doi: 10.4322/rbpv.01902007.

TAVARES-DIAS, M. et al. Haematological changes in Oreochromis niloticus (Osteichthyes: cichlidae) with gill ichthyophthiriasis and saprolegniosis [alterações hematológicas em Oreochromis niloticus (Osteichthyes: cichlidae) com ictioftiríase branquial e saprolegniose]. Boletim do Instituto da Pesca, v.28, n.1, p.1-9, 2002

TAVARES-DIAS, M. et al. Fator de condição e relação hepato e esplenossomática em teleósteos de água doce naturalmente parasitados. Acta Scientiarum. Biological Sciences, v.22, p.533537, 2008. Available from: <http://periodicos.uem.br/ojs/index. php/ActaSciBiolSci/article/view/2944>. Accessed: Nov. 2014. doi: 10.4025/actascibiolsci.v22i0.2944.

TAVARES-DIAS, M. et al. Hematologia de teleósteos brasileiros com infecção parasitária. I. Variáveis do Leporinus macrocephalus Garavello \& Britski, 1988 (Anostomidae) e Piaractus mesopotamicus Holmberg, 1887 (Characidae). Acta Scientiarum, v.21, n.2, p.337-342, 1999.

TAVARES-DIAS, M. et al. Protozoários e metazoários parasitos do cardinal Paracheirodon axelrodi Schultz, 1956 (Characidae), peixe ornamental proveniente de exportador de Manaus, Estado do Amazonas, Brasil. Acta Scientiarum. Biological Sciences, v.31, n.1, p.23-28, 2009.

URBINATI, E.C.; GONÇALVES, F.D. Pacu (Piaractus mesopotamicus). In: BALDISSEROTO, B.; GOMES, L.C. (Eds.). Espécies nativas para piscicultura no Brasil. Santa Maria: UFSM, 2005. p.225-246.

ZUANON, J.A.S. et al. Níveis de proteína bruta em dietas para alevinos de acará-bandeira. Revista Brasileira de Zootecnia, v.35, n.5, p.1893-1896, 2006. Available from: <http://www.scielo.br/ scielo.php?pid $=$ S1516-35982006000700003\&script $=$ sci arttext $>$. Accessed: Nov. 2014. doi: 10.1590/S1516-35982006000700003.

ZUANON, J.A.S. et al. Dietary protein and energy requirements of juvenile fresh water angel fish. Revista Brasileira de Zootecnia, v.38, n.6, p.989-993, 2009. Available from: $<$ http://http://www.scielo.br/scielo.php?script=sci arttext\&p id=S1516-35982009000600003> Accessed: Nov. 2014. doi: 10.1590/S1516-35982009000600003. 